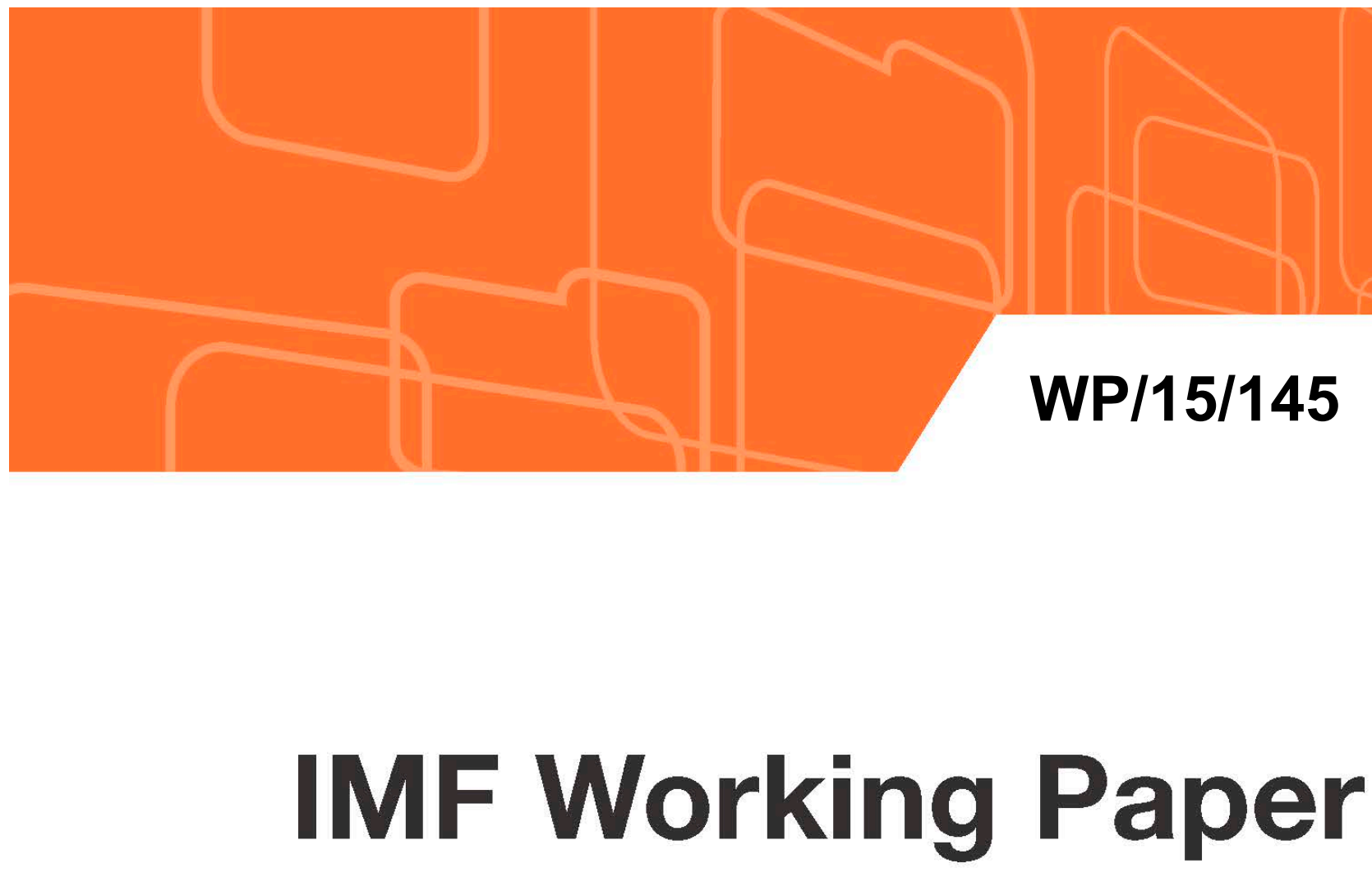

\title{
How Does Post-Crisis Bank Capital Adequacy Affect Firm Investment?
}

by Yangfan Sun and Hui Tong

IMF Working Papers describe research in progress by the author(s) and are published to elicit comments and to encourage debate. The views expressed in IMF Working Papers are those of the author(s) and do not necessarily represent the views of the IMF, its Executive Board, or IMF management.
I $\mathbb{N}$
$N$ T E R
N A T $\|$ O N A L
$M O N E T A R Y$
$F \cup \mathbb{N}$ 


\title{
IMF Working Paper
}

Research Department

\section{How Does Post-Crisis Bank Capital Adequacy Affect Firm Investment? Prepared by Yangfan Sun and Hui Tong ${ }^{1}$}

Authorized for distribution by Nigel Chalk

June 2015

\begin{abstract}
IMF Working Papers describe research in progress by the author(s) and are published to elicit comments and to encourage debate. The views expressed in IMF Working Papers are those of the author(s) and do not necessarily represent the views of the IMF, its Executive Board, or IMF management.
\end{abstract}

\begin{abstract}
We examine the effect of bank capital levels on firm investment drawing on a sample of 11,106 non-financial firms from 2007 to 2013 in 16 advanced economies. We examine two measures of bank capital adequacy, the Tier 1 ratio and a simple leverage ratio, and find that firms with larger external financial needs invest relatively more when domestic financial systems have relatively high leverage ratios. This pattern is more pronounced for those firms that have sound fundamentals, suggesting that bank balance sheets and their willingness to extend credit can be an important factor in determining aggregate investment and growth outcomes. The empirical findings are robust to a range of specifications. Bank Tier 1 capital ratio does not appear to have a significant effect on corporate investment, possibly because a higher Tier 1 ratio also captures a high share of assets with low risk weights.
\end{abstract}

JEL Classification Numbers: G2, G3

Keywords: Bank Capital Adequacy, Firm Investment

Author’s E-Mail Address: Hui Tong, e-mail: htong@imf.org; Yangfan Sun, e-mail: ysun4@imf.org

\footnotetext{
${ }^{1}$ We thank Ravi Balakrishnan, Nigel Chalk, Julian Chow, Stephan Danninger, Giovanni Dell'Ariccia, Selim Ali Elekda, Deniz Igan, Andrew Levin, Erik Lundback, Sophia Zhang and seminar participants at the IMF for helpful comments.
} 


\section{INTRODUCTION}

The repercussions of the global financial crisis of 2007-08 included a chronic shortfall of bank capital and a sustained decline in private investment, even as growth prospects began to recover. During the financial crisis, banks in many advanced economies struggled to raise capital as they faced both losses on their loan portfolios and increases in regulatory capital requirements. At the same time, private investment in advanced economies has declined by an average of 25 percent (see IMF World Economic Outlook, April 2015). While the weakness in investment, on average, can be attributed mainly to the weak outlook for economic activity and demand, the balance sheet weaknesses in the financial sector, and the resulting scarcity of bank-intermediated credit, also plays a role. An extensive literature points to how adverse shocks to bank capital can affect the supply of lending and, consequently, corporate investment (see Bernanke and Lown (1991), Peek and Rosengren (1997, 2000), and Calomiris and Mason (2003)). Indeed, the April 2015 IMF World Economic Outlook also finds evidence that financially constrained firms-i.e., those more reliant on financing from banks and capital markets-were more likely to have lower investment even after adjusting for a range of other factors (see also Claessens, Tong and Wei, 2012).

In order to understand the impact of bank capital on investment, it is important to empirically differentiate two distinct ways that banks can increase their capital adequacy: by raising capital or reducing risk-weighted assets. In the short run, banks tend to meet their regulatory requirements largely by adjust the composition of their assets to lower risk assets 
(largely sovereign debt). ${ }^{2}$ Over a longer horizon, banks can tap capital markets to build up capital and allow themselves the space to expand corporate lending.

This study looks at two distinct measures of capital adequacy. The first measure is the more traditional regulatory capital ratio expressed as the ratio of Tier 1 capital to risk-weighted assets. The second measure is not risk-weighted and is given by the ratio of Tier 1 capital to total assets (the leverage ratio in the Basel III framework). This simple leverage ratio is intended to put a ceiling on the buildup of overall leverage in the banking sector. Globally, Basel III framework sets the minimum leverage ratio at 3 percent, but in July 2013, the U.S. authorities announced that the minimum leverage ratio would be raised to 6 percent for systemically important U.S. banks. ${ }^{3}$

While both the Tier 1 ratio and the leverage ratio are good indicators of capital adequacy, they have different implications for investment. The Tier 1 ratio likely biases bank's asset holding toward government bonds and away from corporate and household credit (since such lending carries a higher risk weight). To investigate the different implications of the two measures for investment, we draw on a large panel that allows heterogeneity across firms, particularly with regard to how much they depend on the availability of credit in their investment decisions. We then examine whether the two different measures of bank capital have a differential impact on those firms that are reliant on external sources of funds to finance their

\footnotetext{
2 According to the European Central Bank's Government Finance Statistics, commercial banks in the European Union increased their holding of government debt from 1.75 trillion euros in 2007 to 2.76 trillion euros in 2013, which accounts for $13.56 \%$ of GDP in 2007 and $20.45 \%$ of GDP in 2013 respectively.

${ }^{3}$ See https://www.fdic.gov/news/news/press/2013/pr13060.html
} 
investment projects. The analysis focuses on the post-crisis period using a sample of 11,106 non-financial firms in sixteen advanced economies.

The main results are as follows

- Those firms with greater external financial needs invest relatively more in those countries that have higher bank leverage ratios. This result is robust to the inclusion of other explanatory variables that might affect banks' willingness to extend credit (such as the system's average ratio of nonperforming loans or the share of intermediation undertaken by banks rather than capital markets).

- The magnitude of this effect is relatively large. For example, the "Engines and Turbines" sector in the U.S. (at the top decile of bank leverage ratio) will invest $9.7 \%$ more than the same sector in France (at the bottom decile of bank leverage ratio).

- The investment effect is even more pronounced when the sample is restricted to the top one-third of firms in terms of underlying fundamentals (as measured by their one year ahead probability of default).

- The empirical findings are robust to changing the sample of countries and restricting to a subset of sectors.

The rest of the paper is organized as follows. In section 2, we review the literature. We describe our methodology and data in section 3 . In section 4 , we present our basic results, and in section 5, we show the results for our robustness checks. We conclude in section 6 . 


\section{LITERATURE}

There has been an extensive literature that shows how adverse shocks to bank capital can affect the supply of lending. While Modigliani and Miller's (1958) paper shows that a firm's capital structure is irrelevant for its operating decisions under certain conditions, the ratio of equity to debt is important for banks since there are tax benefits from debt finance. Moreover, asymmetric information between management and outside investors may lead to more reliance of financing on debt (see Myers and Majluf, 1984). There are also factors, such as deposit insurance that give banks more incentives to use non-equity finance. Since equity finance is more costly to banks, an increase in capital requirements may lead to a shrinking of bank balance sheets and a lower supply of lending.

Empirically, Aiyar, Calomiris and Wieladek (2014) find a large impact of changes in bank-specific capital requirements on bank lending, using a bank regulation database in the United Kingdom from 1998 to 2007. An increase in the capital requirement ratio of 100 basis points, on average, reduces the lending growth by 5.7 percentage points. Brun, Fraisse and Thesmar (2013) investigate the impact of bank capital requirements on corporate lending when French banks transited from Basel I to Basel II in 2008. Based on the loan level data from 2006 to 2011, they estimate the transition to Basel II, which reduced the average capital requirement by about 2 percentage point (from $8 \%$ to $6 \%$ ), led to an increase in average loan size by approximately 10\%. Chiuri, Ferri and Majnoni (2002) explore the impact of introducing bank capital assets requirements (CARs) in emerging economies. Using a sample of 15 emerging economies, they find the enforcement of CARs significantly reduced credit supply, especially for less-well capitalized banks. 
But, other papers do not find such a large effect of capital requirement on bank lending. For example, Kashyap, Stein and Hanson (2010) examine the impact of "substantially heightened" capital requirements on large financial institutions. They find that for a 2.5 basispoint increase in loan rates, there needs to be a ten percentage point increase in the capital ratio. So they conclude that substantially higher capital requirements will have a limited impact on the cost of loans.

Moreover, higher bank capital may reduce the risk of bank run, which can improve the credit rating of banks and subsequently lower their funding costs and lending rates (e.g. Goodhart, Sunirand, and Tsomocos (2006)). Moreover, with the decline of bank run risk, banks will be in a better position to increase their holdings of risky assets such as loans, and reduce their holdings of less risky assets such as cash and government bonds. Empirically, some papers have found that higher pre-crisis bank capital is associated with higher bank lending during crisis. For example, Carlson, Shan and Warusawitharana (2012) find that banks with higher capital have relatively higher loan growth from years 2008 to 2010. Cornetta et al. (2011) also find that bank relying more heavily on equity financing continued to lend more relative to other banks during the 2007-09 crisis. And for earlier crisis episodes, Bernanke and Lown (1991) argue that the shortage of bank equity capital is the most important factor that limits banks' ability to lend in 1990.

In this paper, exploring the cross-country heterogeneity in bank capital adequacy, we find that higher bank leverage ratio is associated with the easing of financial constraint on nonfinancial firms. This finding is robust to the separation of demand-vs-supply effects, the control of the global trend in bank capital requirements and distinguishing between credit-worthy-vsunworthy non-financial firms. Bank Tier 1 capital ratio does not appear to have a significant 
effect on corporate investment, possibly because a higher Tier 1 ratio also captures a high share of assets with low risk weights. ${ }^{4}$ Our paper hence provides new evidence of the effect of bank capital on the real economy.

\section{Methodology AND DATA}

\subsection{Methodology}

It is challenging to identify how bank capital adequacy affects bank's lending. A major difficulty is to distinguish supply and demand effects. The firms' demand for bank credit may be affected by the same economic factors that have an impact on bank capital and banks' lending decisions. Here, the empirical strategy is to use ex ante classifications of firms (in terms of their degree of financial dependence) to isolate the demand effects from the supply effects.

The basic model is the following:

$\frac{I_{i, j, k, t}}{K_{i, j, k, t-1}}=\alpha_{i}+\beta$ FinancialDependence $_{j} *$ BankEquity $_{k, t-1}+\gamma$ Firm Controls $_{i, t-1}+\sum_{k, t} \lambda_{k, t} d_{k, t}+\varepsilon_{i, t}$.

$\frac{I_{i, j, k, t}}{K_{i, j, k, t-1}}$ is the investment to capital ratio for firm $\mathrm{i}$ in sector $\mathrm{j}$ of country $\mathrm{k}$ at time $\mathrm{t}$. We now discuss our key independent variables.

\section{Financial Dependence}

“Financial Dependence" measures a firm's intrinsic dependence on external finance for capital investment at the sector level. We follow the methodology of Rajan and Zingales (1998):

\footnotetext{
${ }^{4}$ In particular, as sovereign bonds have lower risk weights than bank loans, banks under the pressure of meeting Tier-1 capital ratio requirement may have incentives to move assets to sovereign bonds and reduce its lending.
} 


$$
\text { Financial Dependence }=\frac{\text { Capital Expenditure }- \text { Cash Flow }}{\text { Capital Expenditure }}
$$

where "cash flow" denotes cash flow from operations plus reductions in inventories plus decreases in receivables plus increases in payables. The Rajan-Zingales (RZ) index aims to identify sectors that are intrinsically more dependent on external financing for their investment versus those that tend to finance capital projects more from their cash flows.

The RZ index is calculated using data for U.S. firms which are assumed to suffer least from supply-side financing constraints that are likely to disguise their underlying reliance on external finance. While the original Rajan and Zingales (1998) paper covers 40 (mainly SIC 2digit) sectors, we expand the coverage to 90 SIC 3-digit sectors. To calculate the external financing dependence of U.S. firms we calculate the financial dependence ratio for each firm on average for the period 1990-2006 and then take the sector-level median for each SIC 3-digit, as in Tong and Wei (2011). This gives us a sectoral ordering from the least to most financially dependent sectors.

\section{Leverage ratio and Tier 1 ratio}

The key explanatory variable we use to capture bank capital adequacy is the leverage ratio, which is defined as the ratio of Tier 1 capital to total assets within a country, with the banks weighted by assets. An alternative measure used is the Tier 1 capital ratio, which is the ratio of Tier 1 capital to risk-weighted assets within a country.

Figure 1 shows the weighted average Tier 1 ratio in 2007 and 2013. All the countries increased their Tier 1 ratio after the financial crisis. Figure 2 shows the weighted leverage ratio for banks in 2007 and 2013. While all the countries increased their leverage ratios, there were 
still differences in terms of the levels. Specifically, by 2013, the banking sector in the United States was able to maintain a higher leverage ratio than European countries.

In the regressions, for the leverage ratio (and later the Tier 1 ratio), we subtract a global median from the original series for each year. Since 2008, banks in the sample countries have been raising their capital ratios due to regulation requirements, the above detrending then helps us to control for this global movement. Moreover, to further reduce the endogeneity, we use the one-year lagged leverage ratio and Tier 1 ratio as the explanatory variables.

\section{Nonperforming loans ratio}

We also control for the nonperforming loans ratio, which is considered as an important indicator of banks' ability to lend, in part because the associated higher level of risk-weighted assets require that banks provide more capital to meet the regulatory requirements. Again, we use the one-year lagged value of nonperforming loans.

\section{Bank-based financial system index}

We also examine the importance of a country having a bank-based financial system versus a more market based system. Following Čihák et al. (2012), we construct the bank-based financial system index as bank's credit to private sector over the stock market capitalization. As a robustness check, we also use bank credit to the private sector over the stock and bond market capitalization. The key results carry through. 


\section{Firm level control variables}

We use the sales-to-capital ratio as a firm-level control variable. Firms with higher sales to capital ratio are more likely to generate large cash flows that then allow them to finance their investment through the internal accumulation of funds without tapping either banks or financial markets. Another firm-level control variable is Tobin's Q, defined as (Market capitalization + Total Assets - Total Equity)/Total Assets. We expect firms with higher Tobin's Q to have higher investment-to-capital ratios.

\subsection{Sample}

Since we aim to measure the effects of bank capital after crisis, we include countries that experienced financial crisis in 2008 or 2009, based on the database provided by Laeven and Valencia (2012). This implies 16 advanced countries in North American and Europe. The firm level data in our sample is drawn from Worldscope and includes 11,106 non-financial firms. Banking sector data is from Bankscope, which has a good coverage of listed banks in each country (our sample includes 1032 listed banks spread across those 16 countries). Using the balance sheet information on assets and capital, we calculate aggregate indices of the banking sector for each country.

Table 1 shows the number of non-financial firms by country according to Worldscope. As shown in the table, U.S. firms constitute a large portion of the sample. The sample also covers a large number of firms in United Kingdom, France, and Germany.

Table 2 summarizes all the dependent and independent variables at firm-level, sectorlevel, and country-level. There are 48,835 pairs of firm-year in our sample. The median investment-to-capital ratio is 20 percent. But there is significant heterogeneity across firms. For 
example, the investment ratio at the 75 th percentile of firms (in terms of financial dependence) is four times larger than that at the 25 th percentile. The leverage ratio of the bank system is on average 5 percent across country-years. The average Tier 1 capital ratio is 11 percent during this period.

\section{RESULTS}

We present our baseline results in Table 3. The investment-to-capital ratio is our key dependent variable. In Column 1, we include a specification that interacts the bank leverage ratio with the sector-specific financial dependence index. We also include firm fixed effects and country-year-sector fixed effects to control for unobserved characteristics at these levels. The interaction of bank leverage ratio with the financial dependence index is positive and significant at the 5 percent level. ${ }^{5}$ The evidence suggests that firms in sectors with higher external financial dependence will invest more in those countries that maintain a higher bank leverage ratio.

In Column 2, we add firm-level sales-to-capital ratio and Tobin's Q to the regression. The interaction of leverage ratio with the financial dependence index is still statistically significant at the five percent level. Also the coefficient of the sale-to-capital ratio is positive and significant, indicating that firms with higher sales-to-capital are more likely to invest. The coefficient of Tobin's Q is positive and statistically significant at the 1 percent level, which shows that firms with higher Tobin's Q tend to invest more.

\footnotetext{
${ }^{5}$ Column 1 does not include sector-level financial dependence itself because we already include firm fixed effects. And sector-level financial dependence is fully imbedded by firm-level fixed effects. However, the key explanatory variable, leverage ratio*financial dependence, varies at the level of country-sector-year, which is not imbedded by firm fixed effects.
} 
In Column 3, we replace the leverage ratio with the Tier 1 ratio, and interact it with the financial dependence index. The interaction is positive, but not significant. Therefore firms with higher financial dependence did not investment more in countries with higher Tier 1 capital ratio. The result confirms our conjecture that the leverage ratio is more important than the Tier 1 capital ratio in boosting the financial intermediation function of banks.

In Column 4, we include the interaction of nonperforming loans ratio with the financial dependence index. If nonperforming loans ratio matters, we would expect the interaction of nonperforming loans ratio with the financial dependence index to be negative and significant. We do not find evidence to confirm the statistical importance of nonperforming loans.

In Column 5, we include the interaction between the leverage ratio and the financial dependence index, as well as the interaction between the Tier 1 ratio and the financial dependence index. The interaction between the leverage ratio and the financial dependence index is positive and significant. However, the interaction between Tier 1 ratio and financial dependence remains insignificant. These findings are consistent with Kapan and Minoiu (2015) who examine bank loan deals in the U.S. from 2006 and 2010. They find that bank loan deals are unrelated to Tier 1 ratio but positively related to the bank's equity to tangible assets ratio. Our paper provides evidence in a cross-country setting.

In Column 6, we add the interaction between nonperforming loans and financial dependence in addition to the two interactions in Column 5. The result for the interaction between the leverage ratio and financial dependence carries through.

In Column 7, we investigate whether the relative importance of the banking sector matters. We include the interaction of bank-vs-market-based financial system and financial 
dependence. The coefficient for this interaction is not significant. Therefore it is the quality of the banking sector that matters, rather than the relative size of it.

In Column 8, we further include the interaction of lag real GDP growth with financial dependence. It is possible that both the improvement of bank capital adequacy and firm investment are driven by the recovery of the economy in a country. The interaction between lag real GDP growth and financial dependence is significant at the five percent level, which suggests that economic recovery boosts investment. Reassuringly, the interaction of the leverage ratio and financial dependence is still significant at the five percent level.

\section{ROBUSTNESS CHECKS}

\subsection{Firms with "good fundamentals"}

Although we have done much to control for firm characteristics and to examine the financial dependence of the sector, it may be the case that what we are still picking up is that some firms, perhaps some entire sectors, may have such weak fundamentals that it is this, not the supply of bank-intermediated credit, that is of predominant importance for investment decisions. For such firms, it would be rational both for banks not to provide credit and for the firms themselves to not seek financing for new capital projects. We investigate this conjecture by undertaking the same regressions for a subsample of firms. Specifically, we select those firms 
that are in the lowest one-third of the sample for expected default risk. And we use the O-score to measure the one-year-ahead probability of default. ${ }^{6}$

The results are shown in Table 4. The number of observations is reduced from about 46,000 to 18,000 . The previous results regarding the significance of the bank's leverage ratio for financially dependent firms continues to hold in the sub sample. Indeed, the size of the coefficients is larger (coefficients are between 2.226 and 2.735, compared to the range from 0.830 to 1.570 in Table 3), which would seem to support the case that the level of bank capital is even more relevant for financially dependent firms with sound fundamentals (and that constraints on the supply of bank credit are likely to be more binding for such firms' investment outcomes).

In Column 3, the interaction between Tier 1 ratio and financial dependence becomes weakly significant at the 10 percent level, but with a magnitude much smaller than that for the interaction between the leverage ratio and financial dependence. However, the result is not robust. Once we include the leverage ratio and the Tier 1 ratio together in Column 5, the interaction between the leverage ratio and financial dependence remains significant at the 1 percent level, while the interaction between the Tier 1 ratio and financial dependence loses its significance.

6 The O-Score combines nine accounting ratios into a single statistic:

$$
\begin{aligned}
O \text {-Score } & =-1.32-0.41 \text { Size }+6.03 \frac{\text { Total Liability }}{\text { Total Asset }}-1.43 \frac{\text { Working Capital }}{\text { Total Asset }}+0.08 \frac{\text { Current Liabilities }}{\text { Current Asset }} \\
& -2.37 \frac{\text { Net Income }}{\text { Total Asset }}-1.83 \frac{\text { FFO }}{\text { Total Liabilities }}+0.285 F-1.72 G-0.52 \mathrm{H}
\end{aligned}
$$

where Size is the log of total asset divided by the GDP deflator; FFO means pre-tax income plus depreciation and amortization; $F$ is a dummy equal to one if cumulative net income over the previous two years is negative; $G$ is a dummy equal to one if owners' equity is negative; and $H$ is the change in net income. To make sure firms do not change their types across our sample years, we denote the median O-score as firms' O-score, and therefore determine the cutoff. 


\subsection{Sector level regression}

One concern with our dataset is that the share of U.S. firms is relatively large and it could be that U.S. specific factors could be biasing the results. To mitigate this concern, we focus on firms with sound fundamentals and re-run the regressions at the 3-digit SIC sector-country-year level. Every variable is constructed at the sector-country-year level. The new independent variable is the average investment to capital ratio of the firms in the top tercile of fundamentals (lowest expected probability of default).

In this sector-level sample, the share of U.S. observations drops to $25 \%$. To illustrate, at the firm level, U.S. firms dominate in the "Drugs" sector. There are 61 drug firms in the U.S., compared to 42 firms in the other 11 European countries. Once compressed at the sector level, we would have only 1 observation for U.S. and 11 observations of the other European countries.

Table 5 summarizes all the results. Reassuringly, the previous firm-level results are broadly unchanged (Column 1). In Column 2, we also include the sectoral average sales to capital ratio as a control variable. We find that sectors with higher average sales to capital ratio are more likely to invest more but, even after including this variable, the interaction of bank leverage ratio with the financial dependence index remains significant. Sensitivity analysis by including other variables - the Tier 1 ratio, nonperforming loans ratio, and the importance of bank-based financial system — all show those variables to be statistically insignificant.

Finally, in Column 8 of Table 5, we explore an additional robustness check of dropping US sectors from our sample. This reduces the sample size by $25 \%$, but reassuringly, the main results go through. The interaction of equity/assets and financial dependence remains significant at the $5 \%$ level, with a coefficient (1.24) slightly smaller than that for the whole sample (1.36). Hence our key findings are not driven only by US samples. 


\section{CONCLUSIONS}

In this paper, we study how post-2007 bank capital accumulation affects the investment of 11,106 non-financial firms in 16 advanced countries from 2007 to 2013. In particular, we examine two measures of bank capital adequacy: the Tier 1 ratio and a simple leverage ratio. We find that firms with larger external financing needs invest relatively more in countries that are able to maintain higher bank leverage ratios. Moreover, this pattern is particularly stronger for non-financial firms with sound fundamentals, suggesting that bank credit has recovered more for bank's intended borrowers.

The implications are clear. Countries that are proactive in addressing capital shortfalls in their banking system and providing regulatory and other incentives for their banks to raise capital (in the sense of a higher leverage ratio) also see the dividends from such actions in the form of higher investment ratios. Firms with sound fundamentals and solid investment projects are less likely to be constrained by the supply of credit arising from weak bank balance sheets. As a broad guide to the magnitude of this effect, going from the average level of capital in U.S. banks in 2007 to the level that prevailed in 2013, holding all else constant, had the effect of adding around 0.56 percent of GDP to corporate investment. Alternatively, if the U.S. were today to have the average level of Tier 1 capital-to-total assets prevailing among European banks, it would result in 0.73 percent of GDP lower investment, purely from the effect that lower bank capital has on the availability of credit to firms that are reliant on external sources of financing. 


\section{REFERENCE}

Aiyar, Shekhar, Charles W. Calomiris, and Tomasz Wieladek. 2014. Does Macro-prudential Regulation Leak? Evidence from a UK Policy Experiment. Journal of Money, Credit and Banking 46 (1), 181-214.

Bernanke, Ben S., and Cara S. Lown. 1991. The Credit Crunch. Brookings Papers on Economic Activity 2, 205-48.

Brun, Matthieu, Henri Fraisse, and David Thesmar. 2013. The Real Effects of Bank Capital Requirement. Banque de France working paper.

Calomiris, Charles, and Joseph R Mason. 2003. Consequences of Bank Distress during the Great Depression. American Economic Review 93, 937-47.

Carlson, Mark, Hui Shan, and Missaka Warusawitharana. 2013. Capital Ratios and Bank Lending: A Matched Bank Approach. Journal of Financial Intermediation 22 (4), 663-87.

Chiuri, Maria Concetta, Giovanni Ferri, and Giovanni Majnoni. 2002.The Macroeconomic Impact of Bank Capital Requirements in Emerging Economies: Past Evidence to Assess the Future. Journal of Banking \& Finance 26, 881-904.

Čihák, Martin, Aslı Demirgüç-Kunt, Erik Feyen, and Ross Levine. 2012. Benchmarking Financial Systems around the World, World Bank Policy Research Working Paper 6175.

Claessens, Stijn, Hui Tong and Shang-Jin Wei. 2012. From the Financial Crisis to the Real Economy: Using Firm-Level Data To Identify Transmission Channels. Journal of International Economics 88, 375-387.

Cornett, Marcia Millon, Jamie John McNutt, Philip E. Strahan, and Hassan Tehranian. 2011. Liquidity Risk Management and Credit Supply in the Financial Crisis, Journal of Financial Economics 101 (2), 297-312.

Goodhart, Charles A.E., Sunirand Pojanart, and Dimitrios P. Tsomocos. 2006. A Model to Analyse Financial Fragility, Economic Theory 27, 107-42.

International Monetary Fund.2015. Private Investment: What's the Holdup? IMF World Economic Outlook.

Kapan, Tumer, and Camelia Minoiu. 2015. Balance Sheet Strength and Bank Lending During the Global Financial Crisis, Available at SSRN: http://ssrn.com/abstract=2247185

Kashyap, Anil K., Jeremy C. Stein, and Samuel Hanson. 2010. An Analysis of the Impact of Substantially Heightened Capital Requirements on Large Financial Institutions. Harvard University working paper. 
Laeven, Luc, and Fabian Valencia. 2013. Systemic Banking Crises Database, IMF Economic Review 61, 225-70.

Modigliani, Franco, and Merton H. Miller. 1958. The Cost of Capital, Corporation Finance and the Theory of Investment. American economic review 48(3), 261-97.

Myers, Stewart C., and Nicholas S. Majluf. 1984. Corporate Financing and Investment Decisions When Firms Have Information that Investors do not Have. Journal of Financial Economics 13(2), 187-221.

Peek, Joe, and Eric Rosengren. 1997. The International Transmission of Financial Shocks: The Case of Japan. American Economic Review 87 (4), 495-505.

Peek, Joe, and Eric Rosengren. 2000. Collateral Damage: Effects of the Japanese Bank Crisis on Real Activity in the United States. American Economic Review 90 (1), 30-45.

Rajan, Raghuram, and Luigi Zingales. 1998. Financial Dependence and Growth. American Economic Review 88 (3), 559-86.

Tong, Hui, and Shang-Jin Wei. 2011. The Composition Matters: Capital Inflows and Liquidity Crunch During a Global Economic Crisis. Review of Financial Studies 24, 2023-52. 
Figure 1. Tier 1 Ratio (Tier 1 Capital/Risk-weighted Assets)

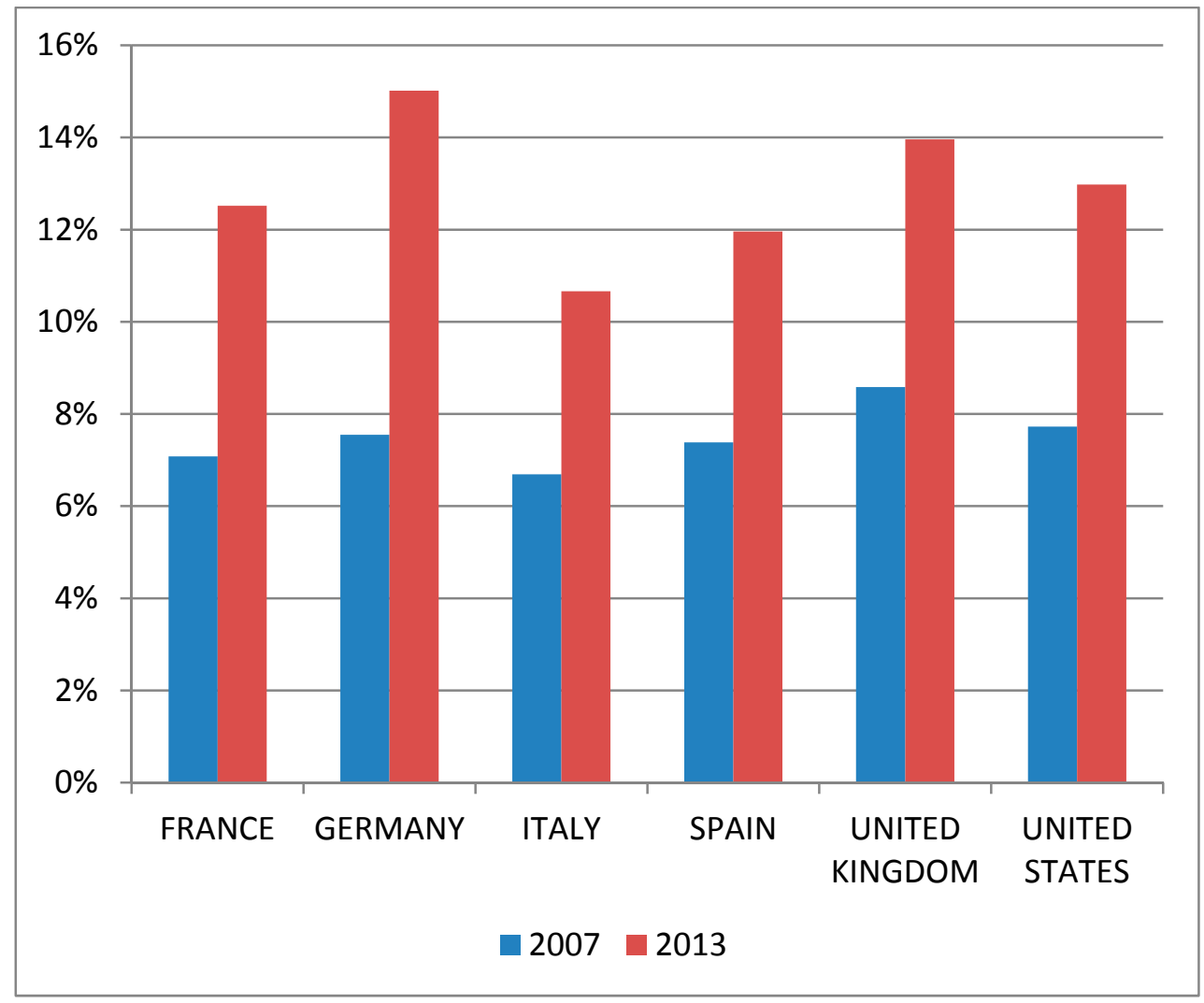

Source: Bankscope 
Figure 2. Leverage Ratio (Tier 1 Capital/Total Assets)

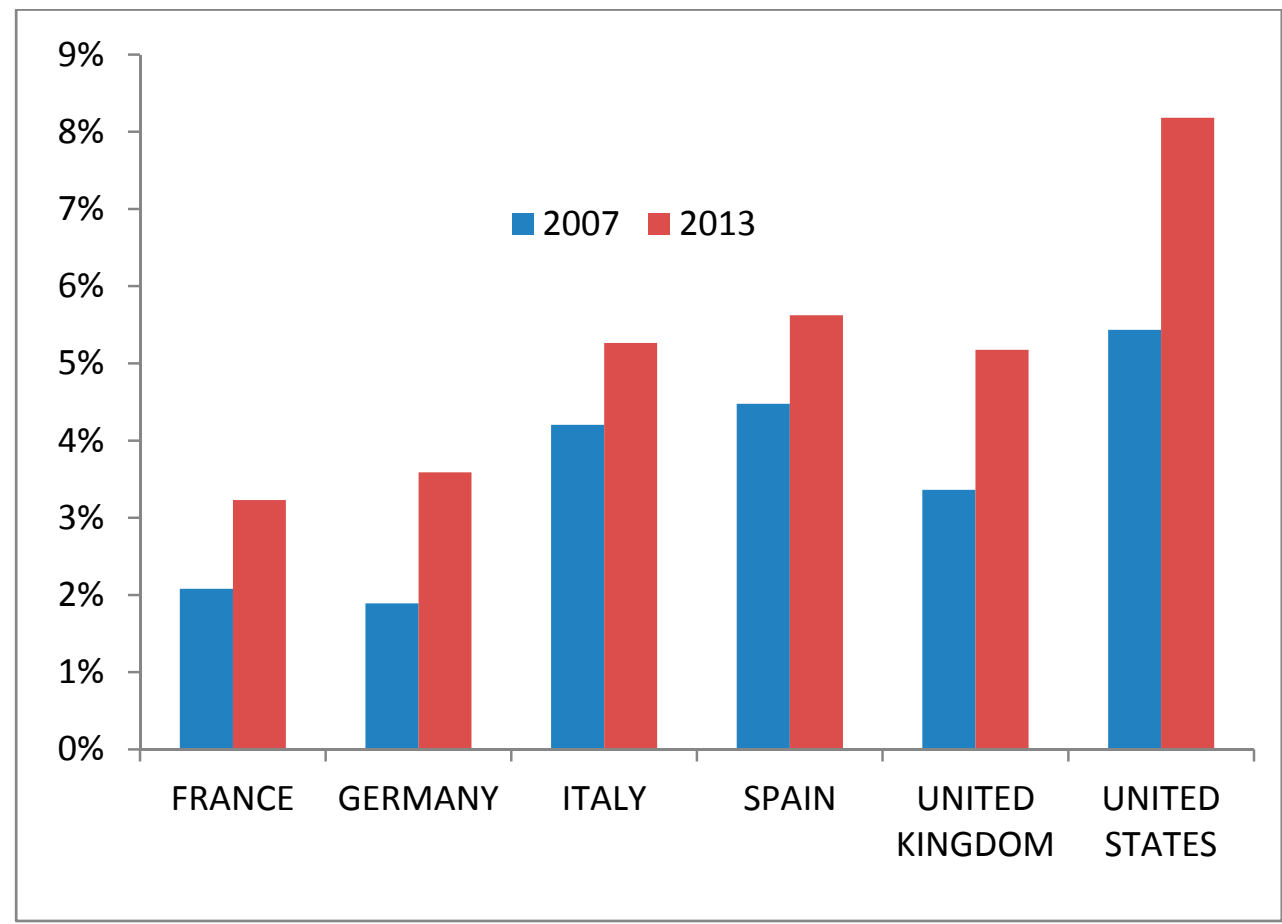

Source: Bankscope 
Table 1. The number of Listed Non-financial Firms

\begin{tabular}{ll}
\hline Country & \# of Firms \\
\hline Austria & 67 \\
Belgium & 102 \\
France & 658 \\
Germany & 643 \\
Greece & 244 \\
Ireland & 62 \\
Italy & 234 \\
Luxembourg & 22 \\
Netherlands & 144 \\
Portugal & 42 \\
Slovenia & 36 \\
Spain & 118 \\
Sweden & 445 \\
Switzerland & 199 \\
United Kingdom & 1,575 \\
United States & 6,515 \\
\hline
\end{tabular}


Table 2: Summary Statistics

\begin{tabular}{|c|c|c|c|c|c|c|c|c|}
\hline Variable & $\mathrm{N}$ & Mean & St Dev & p50 & p25 & p75 & Min & Max \\
\hline \multicolumn{9}{|l|}{ Firm-year level: full sample } \\
\hline Investment/Capital ratio & 48835 & 0.46 & 1.04 & 0.20 & 0.10 & 0.40 & 0.00 & 8.30 \\
\hline Sales/Capital ratio & 48818 & 22.34 & 52.29 & 5.96 & 1.95 & 17.60 & 0.00 & 377.70 \\
\hline Tobin's Q & 43950 & 1.87 & 1.77 & 1.32 & 1.00 & 1.97 & 0.48 & 12.60 \\
\hline O score & 50033 & 5.75 & 35.27 & -1.46 & -3.07 & 1.00 & -9.27 & 282.41 \\
\hline \multicolumn{9}{|c|}{ Firm-year level: Bottom 33\% percentile based on O score } \\
\hline Investment/Capital ratio & 18088 & 0.39 & 0.72 & 0.22 & 0.13 & 0.40 & 0.00 & 8.30 \\
\hline Sales/Capital ratio & 18087 & 17.94 & 39.37 & 6.53 & 2.92 & 15.20 & 0.00 & 377.70 \\
\hline Tobin's Q & 18111 & 1.77 & 1.23 & 1.42 & 1.05 & 2.06 & 0.48 & 12.60 \\
\hline O score & 18177 & -3.40 & 4.25 & -3.38 & -4.61 & -2.45 & -9.27 & 282.41 \\
\hline \multicolumn{9}{|l|}{ 3-digit sector-year level: full sample } \\
\hline Average Investment/Capital ratio & 8342 & 0.35 & 0.65 & 0.20 & 0.11 & 0.35 & 0.00 & 8.30 \\
\hline Average Sales/Capital ratio & 8173 & 18.09 & 37.85 & 6.26 & 2.84 & 15.69 & 0.00 & 377.70 \\
\hline \multicolumn{9}{|c|}{ 3-digit sector-year level: Bottom 33\% percentile based on O score } \\
\hline Average Investment/Capital ratio & 4919 & 0.34 & 0.58 & 0.21 & 0.13 & 0.35 & 0.00 & 8.30 \\
\hline Average Sales/Capital ratio & 4921 & 17.79 & 38.72 & 6.26 & 2.95 & 14.68 & 0.00 & 377.70 \\
\hline \multicolumn{9}{|l|}{ Country-year level } \\
\hline Leverage Ratio & 111 & 0.05 & 0.02 & 0.05 & 0.04 & 0.06 & 0.00 & 0.11 \\
\hline Tier 1 Ratio & 111 & 0.11 & 0.03 & 0.10 & 0.08 & 0.12 & 0.01 & 0.18 \\
\hline Nonperforming loans ratio & 111 & 0.06 & 0.07 & 0.04 & 0.02 & 0.06 & 0.00 & 0.36 \\
\hline Bank-based financial system & 100 & 3.16 & 2.48 & 2.36 & 1.39 & 4.35 & 0.33 & 11.75 \\
\hline Real GDP growth rate & 111 & 0.18 & 3.08 & 0.61 & -1.62 & 2.20 & -9.28 & 6.71 \\
\hline
\end{tabular}

Note: The investment (sales)-to-capital ratio is the ratio of investment (sales) to lag of capital. Average investment (sales)-tocapital ratio is the average ratio at 3 digits SIC code level. O score is the one-year-ahead probability of default, as defined in Ohlson (1980). Higher value of O score indicates higher probability to default. Financial dependence is a sector's intrinsic dependence on external finance for capital expenditures as in Rajan and Zingales (1998). Leverage ratio is defined as a country's total Tier 1 capital of listed banks over total assets. Tier 1 ratio is defined as a country's total Tier 1 capital over total riskweighted assets. A global trend is subtracted from both of them. Nonperforming loans ratio is the weighted ratio at country level. Bank-based financial system is a ratio of private credit by banks to stock market capitalization. 
Table 3. Firm level regression for full sample

\begin{tabular}{|c|c|c|c|c|c|c|c|c|}
\hline Variables & $(1)$ & $(2)$ & (3) & (4) & (5) & (6) & (7) & (8) \\
\hline \multirow[t]{2}{*}{ Leverage ratio *Financial dependence } & $0.847 * *$ & $0.830 *$ & & & $1.351^{* * *}$ & $1.570 * * *$ & $1.426 * * *$ & $1.112 * *$ \\
\hline & $(0.415)$ & $(0.425)$ & & & $(0.458)$ & $(0.479)$ & $(0.529)$ & $(0.516)$ \\
\hline \multirow[t]{2}{*}{ Tier 1 ratio*Financial dependence } & & & 0.140 & & -0.456 & -0.434 & -0.519 & -0.239 \\
\hline & & & $(0.282)$ & & $(0.314)$ & $(0.320)$ & $(0.355)$ & $(0.364)$ \\
\hline \multirow[t]{2}{*}{ Non-performing loans ratio*Financial dependence } & & & & 0.0673 & & 0.180 & 0.190 & $0.311 * *$ \\
\hline & & & & $(0.130)$ & & $(0.145)$ & $(0.149)$ & $(0.159)$ \\
\hline \multirow[t]{2}{*}{ Bank-based financial system index*Financial dependence } & & & & & & & -0.00324 & 0.00142 \\
\hline & & & & & & & $(0.00648)$ & $(0.00644)$ \\
\hline \multirow[t]{2}{*}{ Real GDP growth*Financial dependence } & & & & & & & & $0.00367 * *$ \\
\hline & & & & & & & & $(0.00180)$ \\
\hline \multirow[t]{2}{*}{ Lag Sales/Capital } & & $0.00255^{* * *}$ & $0.00255^{* * *}$ & $0.00255^{* * *}$ & $0.00256 * * *$ & $0.00255^{* * *}$ & $0.00243 * * *$ & $0.00243 * * *$ \\
\hline & & $(0.000424)$ & $(0.000424)$ & $(0.000424)$ & $(0.000424)$ & $(0.000424)$ & $(0.000456)$ & $(0.000457)$ \\
\hline \multirow[t]{2}{*}{ Lag Tobin's Q } & & $0.0898 * * *$ & $0.0899 * * *$ & $0.0900 * * *$ & $0.0898 * * *$ & $0.0899 * * *$ & $0.0881 * * *$ & $0.0881 * * *$ \\
\hline & & $(0.0105)$ & $(0.0105)$ & $(0.0105)$ & $(0.0105)$ & $(0.0105)$ & $(0.0107)$ & $(0.0107)$ \\
\hline Firm fixed effects & Y & $\mathrm{Y}$ & Y & $\mathrm{Y}$ & $\mathrm{Y}$ & $\mathrm{Y}$ & $\mathrm{Y}$ & $\mathrm{Y}$ \\
\hline Country-year-sector fixed effects & Y & Y & Y & Y & Y & $\mathrm{Y}$ & Y & Y \\
\hline R-squared & 0.440 & 0.490 & 0.490 & 0.490 & 0.490 & 0.490 & 0.502 & 0.502 \\
\hline Number of firms & 9430 & 8199 & 8199 & 8199 & 8199 & 8199 & 8134 & 8134 \\
\hline Number of Observations & 46050 & 41371 & 41371 & 41371 & 41371 & 41371 & 40251 & 40251 \\
\hline
\end{tabular}

Note: The sample is for listed nonfinancial firms in 16 countries. The dependent variable is the firm level investment-to-capital ratio. Financial dependence is a sector's intrinsic dependence on external finance for capital expenditures as in Rajan and Zingales (1998). Leverage ratio is defined as a country's total Tier 1 capital of listed banks over total assets. Tier 1 ratio is defined as a country's total Tier 1 capital over total risk-weighted assets. A global trend is subtracted from both of them. Nonperforming loans ratio is the weighted ratio at country level. Bank-based financial system is a ratio of private credit by banks to stock market capitalization. All the country level variables are in one-year lag. Lag Sales-to-capital ratio is the ratio of sales to lag of capital at the firm level. Standard errors are clustered at the country-year-and-3 digit-SIC level. Robust standard errors are in brackets, $* * * p<0.01, * * p<0.05, * p<0.1$ 
Table 4. Firm level regression for the firms with strong fundamentals

\begin{tabular}{|c|c|c|c|c|c|c|c|c|}
\hline & $(1)$ & $(2)$ & (3) & $(4)$ & (5) & (6) & $(7)$ & $(8)$ \\
\hline \multirow[t]{2}{*}{ Leverage ratio *Financial dependence } & $2.735 * * *$ & $2.534 * * *$ & & & $2.552 * * *$ & $2.532 * * *$ & $2.276 * * *$ & $2.226 * * *$ \\
\hline & $(0.844)$ & $(0.841)$ & & & $(0.758)$ & $(0.741)$ & $(0.704)$ & $(0.715)$ \\
\hline \multirow[t]{2}{*}{ Tier 1 ratio*Financial dependence } & & & $0.873^{*}$ & & -0.0196 & -0.0206 & -0.256 & -0.225 \\
\hline & & & $(0.526)$ & & $(0.457)$ & $(0.455)$ & $(0.488)$ & $(0.503)$ \\
\hline \multirow[t]{2}{*}{ Non-performing loans ratio*Financial dependence } & & & & -0.173 & & -0.0265 & -0.0180 & -0.000892 \\
\hline & & & & $(0.186)$ & & $(0.166)$ & $(0.173)$ & $(0.181)$ \\
\hline \multirow[t]{2}{*}{ Bank-based financial system index*Financial dependence } & & & & & & & -0.00640 & -0.00586 \\
\hline & & & & & & & $(0.00456)$ & $(0.00458)$ \\
\hline \multirow[t]{2}{*}{ Real GDP growth*Financial dependence } & & & & & & & & 0.000542 \\
\hline & & & & & & & & $(0.00150)$ \\
\hline \multirow[t]{2}{*}{ Lag Sales/Capital } & & $0.00351 * * *$ & $0.00351 * * *$ & $0.00352 * * *$ & $0.00351 * * *$ & $0.00351 * * *$ & $0.00378 * * *$ & $0.00378 * * *$ \\
\hline & & $(0.000753)$ & $(0.000755)$ & $(0.000757)$ & $(0.000753)$ & $(0.000754)$ & $(0.000821)$ & $(0.000821)$ \\
\hline \multirow[t]{2}{*}{ Lag Tobin's Q } & & $0.0921 * * *$ & $0.0924 * * *$ & $0.0921 * * *$ & $0.0921 * * *$ & $0.0920 * * *$ & $0.0855^{* * *}$ & $0.0855^{* * *}$ \\
\hline & & $(0.0148)$ & $(0.0148)$ & $(0.0149)$ & $(0.0148)$ & $(0.0149)$ & $(0.0136)$ & $(0.0136)$ \\
\hline Firm fixed effects & Y & Y & $\mathrm{Y}$ & Y & $\mathrm{Y}$ & $\mathrm{Y}$ & Y & $\mathrm{Y}$ \\
\hline Country-year-sector fixed effects & $\mathrm{Y}$ & $\mathrm{Y}$ & $\mathrm{Y}$ & $\mathrm{Y}$ & $\mathrm{Y}$ & $\mathrm{Y}$ & $\mathrm{Y}$ & $\mathrm{Y}$ \\
\hline R-squared & 0.641 & 0.655 & 0.655 & 0.654 & 0.655 & 0.655 & 0.672 & 0.672 \\
\hline Number of firms & 3422 & 3408 & 3408 & 3408 & 3408 & 3408 & 3384 & 3384 \\
\hline Number of Observations & 18088 & 18036 & 18036 & 18036 & 18036 & 18036 & 17470 & 17470 \\
\hline
\end{tabular}

Note: The sample is for list nonfinancial firms that are in the bottom 33\% percentile group based on O-score. O score is the one-year-ahead probability of default, as defined in Ohlson (1980). Higher value of $O$ score indicates higher probability to default. The dependent variable is the firm level investment-to-capital ratio. Financial dependence is a sector's intrinsic dependence on external finance for capital expenditures as in Rajan and Zingales (1998). Leverage ratio is defined as a country's total Tier 1 capital of listed banks over total assets. Tier 1 ratio is defined as a country's total Tier 1 capital over total risk-weighted assets. A global trend is subtracted from both of them. Nonperforming loans ratio is the weighted ratio at country level. Bank-based financial system is a ratio of private credit by banks to stock market capitalization. All the country level variables are in one-year lag. Lag Sales-to-capital ratio is the ratio of sales to lag of capital at the firm level. Standard errors are clustered at the country-year-and-3 digit-SIC level. Robust standard errors are in brackets, $* * * p<0.01, * * p<0.05, * p<0.1$. 
Table 5. Sector level regression

\begin{tabular}{|c|c|c|c|c|c|c|c|c|}
\hline & $(1)$ & $(2)$ & (3) & (4) & (5) & (6) & (7) & (8) \\
\hline \multirow[t]{2}{*}{ Equity/Assets*Financial dependence } & $0.927^{*}$ & $1.076^{* *}$ & & & $1.131 * * *$ & $1.067^{* *}$ & $1.364 * * *$ & $1.235^{* *}$ \\
\hline & $(0.486)$ & $(0.423)$ & & & $(0.418)$ & $(0.446)$ & $(0.492)$ & $(0.483)$ \\
\hline \multirow[t]{2}{*}{ Tier 1 ratio*Financial dependence } & & & 0.297 & & -0.0617 & 0.0141 & -0.338 & -0.319 \\
\hline & & & $(0.332)$ & & $(0.348)$ & $(0.393)$ & $(0.436)$ & $(0.461)$ \\
\hline \multirow[t]{2}{*}{ Non-performing loans ratio*Financial dependence } & & & & 0.0917 & & 0.0957 & 0.161 & 0.143 \\
\hline & & & & $(0.121)$ & & $(0.127)$ & $(0.135)$ & $(0.144)$ \\
\hline \multirow[t]{2}{*}{ Bank-based financial system index*Financial dependence } & & & & & & & -0.00376 & -0.00398 \\
\hline & & & & & & & $(0.00382)$ & $(0.00397)$ \\
\hline \multirow[t]{2}{*}{ Real GDP growth*Financial dependence } & & & & & & & 0.00241 & 0.00236 \\
\hline & & & & & & & $(0.00160)$ & (0.00179) \\
\hline \multirow[t]{2}{*}{ Lag Average Sales/Capital } & & $0.00214^{* *}$ & $0.00212^{* *}$ & $0.00212^{* *}$ & $0.00214 * *$ & $0.00213^{* *}$ & $0.00253 * * *$ & $0.00224 * *$ \\
\hline & & $(0.000825)$ & $(0.000822)$ & $(0.000822)$ & $(0.000828)$ & $(0.000831)$ & $(0.000901)$ & $(0.00101)$ \\
\hline \multirow[t]{2}{*}{ Lag Average Tobin's Q } & & $0.0893 * * *$ & $0.0892 * * *$ & $0.0898 * * *$ & $0.0894 * * *$ & $0.0896 * * *$ & $0.0843^{* * *}$ & $0.0808 * * *$ \\
\hline & & $(0.0189)$ & $(0.0188)$ & $(0.0189)$ & $(0.0188)$ & $(0.0188)$ & $(0.0192)$ & $(0.0220)$ \\
\hline Country-sector fixed effects & $\mathrm{Y}$ & $\mathrm{Y}$ & $\mathrm{Y}$ & $\mathrm{Y}$ & $\mathrm{Y}$ & $\mathrm{Y}$ & $\mathrm{Y}$ & $\mathrm{Y}$ \\
\hline Country-year fixed effects & $\mathrm{Y}$ & $\mathrm{Y}$ & $\mathrm{Y}$ & $\mathrm{Y}$ & $\mathrm{Y}$ & $\mathrm{Y}$ & $\mathrm{Y}$ & $\mathrm{Y}$ \\
\hline R-squared & 0.540 & 0.553 & 0.553 & 0.553 & 0.553 & 0.553 & 0.589 & 0.585 \\
\hline Number of country-sectors & 700 & 699 & 699 & 699 & 699 & 699 & 695 & 541 \\
\hline Number of Observations & 4759 & 4754 & 4754 & 4754 & 4754 & 4754 & 4507 & 3390 \\
\hline
\end{tabular}

Note: The sample is for list nonfinancial firms that are in the bottom 33\% percentile group based on O-score. O score is the one-year-ahead probability of default, as defined in Ohlson (1980). Higher value of O score indicates higher probability to default. The dependent variable is the average of investment-to-capital ratio at the 3 digits SIC code level. Financial dependence is a sector's intrinsic dependence on external finance for capital expenditures as in Rajan and Zingales (1998). Leverage ratio is defined as a country's total Tier 1 capital of listed banks over total assets. Tier 1 ratio is defined as a country's total Tier 1 capital over total risk-weighted assets. A global trend is subtracted from both of them. Nonperforming loans ratio is the weighted ratio at country level. Bank-based financial system is a ratio of private credit by banks to stock market capitalization. All the country level variables are in one-year lag. Average sales-to-capital ratio (and Tobin's $Q$ ) is the average value at 3 digits SIC code level. Standard errors are clustered at the country-year level. Robust standard errors are in brackets, $* * * p<0.01, * * p<0.05, * p<0.1$. 